\title{
Nagyelma n. gen. for Ennea aliena Bavay and Dautzenberg, 1912 (Gastropoda: Eupulmonata: Streptaxidae)
}

\author{
B. PÁLL-GERGELY ${ }^{1 *}$ and A. HUNYADI ${ }^{2}$ \\ ${ }^{1}$ Centre for Agricultural Research, Plant Protection Institute, \\ Eötvös Loránd Research Network, Herman Ottó Street 15, \\ Budapest, H-1022, Hungary \\ ${ }^{2}$ Adria sétány $10 \mathrm{G} 2 / 5$., Budapest $\mathrm{H}-1148$, Hungary
}

(Received: 04 September 2020; accepted: 22 September 2020)

\begin{abstract}
Nagyelma n. gen. is erected for the northern Vietnamese Ennea aliena Bavay and Dautzenberg, 1912. The most closely related genus is probably Elma $\mathrm{H}$. Adams, 1866, which also has a high-spired shell but differs from the new genus in the absence of a parietal tooth, the pointed-ovoid shell shape, and the penial sheath, which covers only half of the penis.
\end{abstract}

\footnotetext{
Keywords: Taxonomy, systematics, Vietnam, anatomy, conchology, shell.

Registration code: http://zoobank.org/urn:lsid:zoobank.org:pub:1B989572-F4BB-4F0C-9757CBA7480B8C89
}

The Streptaxidae are pantropical carnivorous terrestrial snails ("hunter snails"), represented in mainland Southeast Asia with ten genera Siriboon et al. (in press). Among them, only Elma H. Adams, 1866 (Fig. 1A-C) possesses a high-spired shell. All other genera are characterized by flattened or globular shells (Páll-Gergely et al., 2015). Members of the speciose genus Sinoennea Kobelt, 1904 are also high-spired see Páll-Gergely et al. (2020), and had been classified in the Streptaxidae until the family Diapheridae Panha and Naggs, 2010 was introduced based on anatomical and molecular information (Sutcharit et al., 2010).

Ennea aliena Bavay and Dautzenberg, 1912 (Fig. 1D-G) is an enigmatic species from northern Vietnam. Despite having a high-spired shell, it differs from all Elma species by the presence of a parietal tooth, and the cylindrical shell (i.e. domed, rather than pointed apex). In contrast, Elma species lack a parietal tooth and have pointed-ovoid shells. Ennea aliena has been classified in the genus Indoennea Kobelt, 1904 by Schileyko (2011). However, Indoennea is a junior synonym of Sinoennea, a genus with three to six (in most cases four), characteristically arranged apertural barriers (Peile, 1935; PállGergely et al., 2020). Thus, based on the apertural barriers, E. aliena is clearly not a member of Sinoennea. Based on the somewhat similar shell, we hypothesized that E. aliena is probably the closest relative of Elma, and probably deserves its own genus. However, in

*Corresponding author; e-mail: pallgergely2@gmail.com 


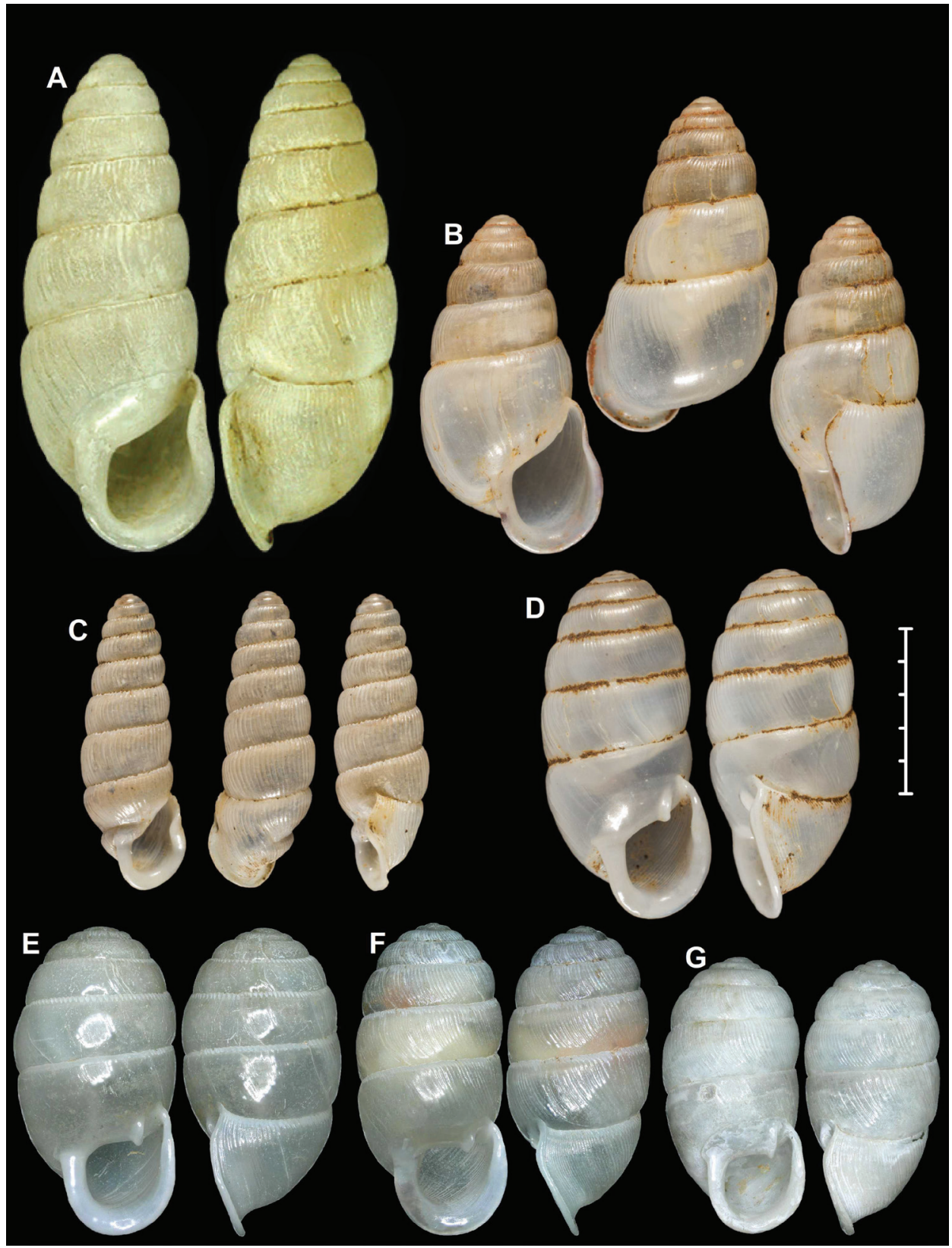

Fig. 1. Shells of Elma H. Adams, 1866 (A-C) species and Nagyelma aliena (Bavay and Dautzenberg, 1912) (D-G). A: Elma swinhoei (H. Adams, 1866), lectotype (NHMUK 1866.5.9.14/1) (from Hwang 2014); B: Elma tonkiniana (Bavay and Dautzenberg, 1904), (syntype, MNHN-IM-2000-30988); C: Elma fultoni (Bavay and Dautzenberg, 1912), syntype (MNHN-IM-2000-30938);

D: Nagyelma aliena (Bavay and Dautzenberg, 1912), syntype (MNHN-IM-2000-30879); E: N. aliena, Vn12-225; F: N. aliena, 2020/38; G: N. aliena, Vn12-268.

Scale represents $5 \mathrm{~mm}$. Photos: M. Caballer (B-D), B. Páll-Gergely (E-G) 
the absence of anatomical information, we refrained from erecting a genus for E. aliena (Páll-Gergely et al., 2015). In the present paper we first describe the anatomy of Ennea aliena based on newly-collected material, and erect a new genus for that species based on the anatomical and conchological differences from Elma.

\title{
Materials and Methods
}

Ten to 30 photographs were taken of each shell using Keyence LHX5000 digital microscope and merged to create a single image using Photoshop. The ethanol-preserved specimen was dissected under a Zeiss stereomicroscope, and photographs were taken using a Keyence LHX5000 digital microscope. Abbreviations: HA: Collection András Hunyadi, (Budapest, Hungary); HE: Collection Christa Hemmen (Wiesbaden, Germany); HNHM: Hungarian Natural History Museum (Budapest, Hungary); MNHN: Muséum National d'Histoire Naturelle (Paris, France).

\section{Taxonomy and Systematics}

\author{
Family Streptaxidae Gray, 1860 \\ Streptaxidae Gray, 1860: 268.
}

\section{Subfamily Streptaxinae Gray, 1860}

Remarks: In an earlier publication, we discussed the systematic position of Elma (Páll-Gergely et al., 2015), which has similar anatomical traits to that of Nagyelma n. gen. Based on the morphology of the reproductive anatomy, Elma can be classified either in the in the subfamily Streptaxinae or in Gibbinae sensu Schileyko (2000). The former group ranges through tropical Asia, Africa and South America. In contrast, the Gibbinae (at least the group probably containing Gibbus Montfort, 1810, see Rowson et al., 2010 and PállGergely et al., 2015) are mostly distributed in the Seychelles and the Mascarene islands, while the extinct type genus Gibbus is known form Mauritius. An Indoartemon Forcart, 1946 species from Sri Lanka clustered together with the South American Streptartemon Kobelt, 1905, and Streptaxis Gray, 1837 in the phylogenetic tree of Rowson et al. (2010). Indoartemon ranges to SE Asia, and several genera of similar conchological and anatomical traits inhabit that area. Thus, it is highly probable that at least some of the Southeast Asian streptaxid genera are members of Streptaxinae. Accordingly, it is more likely that Elma and Nagyelma n. gen. belong to the Streptaxinae than to the Gibbinae.

\section{Nagyelma Páll-Gergely, n. gen.}

Type species: Ennea aliena Bavay and Dautzenberg, 1912.

Diagnosis: Shell cylindrical, apex domed, surface glossy with fine ribs or simply a mamillated suture; aperture subcircular with pointed sinulus, peristome almost discontinuous, parietal callus only with thin calcareous layer; parietal lamella short and relatively 
low; upper margin of aperture curved backwards. Penis slender, long, its entire length covered by a penial sheath, internally with brown papillae bearing brown hooks; vas deferens enters penis after forming a loop under the penial sheath; penial retractor muscle inserts at the penis-vas deferens junction; vagina relatively long, internally with elevated folds converging towards atrium, and tiny horizontally arranged tiny pockets.

Differential diagnosis: Nagyelma n. gen. is probably most closely related to Elma (Fig. 1A-C; see Varga, 2012 and Páll-Gergely et al., 2015), which is similar in shell size and sculpture. However, shells of Elma species are all pointed-ovoid, whereas Nagyelma n. gen. is clearly ovoid with a blunt (domed) apical part. Furthermore, Elma species lack the short parietal lamella present in Nagyelma n. gen. Regarding the reproductive anatomy, the bursa copulatrix starts in a more proximal position in Elma, making the vagina shorter than in Nagyelma n. gen. The penial sheath covers only the distal half of the penis in Elma, whereas the entire penis is covered in Nagyelma n. gen.

Sinoennea is characterized by numerous (mostly four), apertural barriers (1 parietal, 2 palatal, 1 columellar), and they are built during the juvenile stages as well. In contrast, Nagyelma n. gen. has only a weak, short parietal lamella, and no apertural dentition is built during the juvenile stage.

Etymology: This new genus is dedicated to Barnabás Nagy (1921-2020), a prominent agrozoologist and orthopterologist, who worked in our institute for 63 years. The generic name Nagyelma is a combination of the family name Nagy (pronunciation: 'npt) and Elma, referring to the probably most closely related genus. Grammatical gender: feminine.

Remarks: The African Ennea, in which N. aliena has been classified, is certainly not closely related to $N$. aliena due to morphological dissimilarities and biogeographical reasons. The most closely related genus is the also Southeast Asian Elma. Nagyelma n. gen. is erected here in order to avoid Elma becoming a wastebasket taxon (Páll-Gergely, 2017). The reproductive anatomy of Elma indicates that it does not belong to the Diapheridae, but to the Streptaxidae, although its classification in one of the subfamilies defined by Schileyko (2000) is questionable (Páll-Gergely et al., 2015).

\section{Nagyelma aliena (Bavay and Dautzenberg, 1912)}

(Fig. 1D-G, Figs 2, 3, 4)

Ennea aliena Bavay and Dautzenberg, 1912: 3, plate 1, figs 4, 5

Indoennea (?) aliena, - Schileyko, 2011:26.

"Ennea" aliena, - Páll-Gergely et al., 2015: 162, fig. 11.

Type locality: "Ny-Nham et Nui-Moc (Than-Hoa), Tonkin."

Types examined: syntype, MNHN-IM-2000-30879.

Additional material examined: Vietnam, Thanh Hóa Prov., road no. 15 Ngoc Lac to Lang Chanh, $4.8 \mathrm{~km}$ to Land Chanh, $20^{\circ} 07.734^{\prime} \mathrm{N}, 105^{\circ} 16.315^{\prime} \mathrm{E}$ (code of coll. site: Vn12-225), leg. Hemmen, 19 October 2011, HE/4+1 live collected shell; Same locality (code of coll. site: Vn12-225A), leg. Ch. and J. Hemmen, 14 April 2012, HE/4; Vietnam, Thanh Hóa Prov., km 585 on road no. 15, Yen Cat to Ngoc Lac, 1 km right off road no. $15,19^{\circ} 45.589^{\prime} \mathrm{N}, 1^{\circ} 25.521^{\prime} \mathrm{E}$ (code of coll. site: Vn12-268), leg. Hemmen, 14.04.2012, HE/3; Vietnam, Thanh Hóa Prov., road no. 15 Ngoc Lac to Lang Chanh, $7.3 \mathrm{~km}$ to Land Chanh, $20^{\circ} 07.315^{\prime} \mathrm{N}, 105^{\circ} 17.997 ' \mathrm{E}$ (code of coll. site: Vn12-269), leg. 


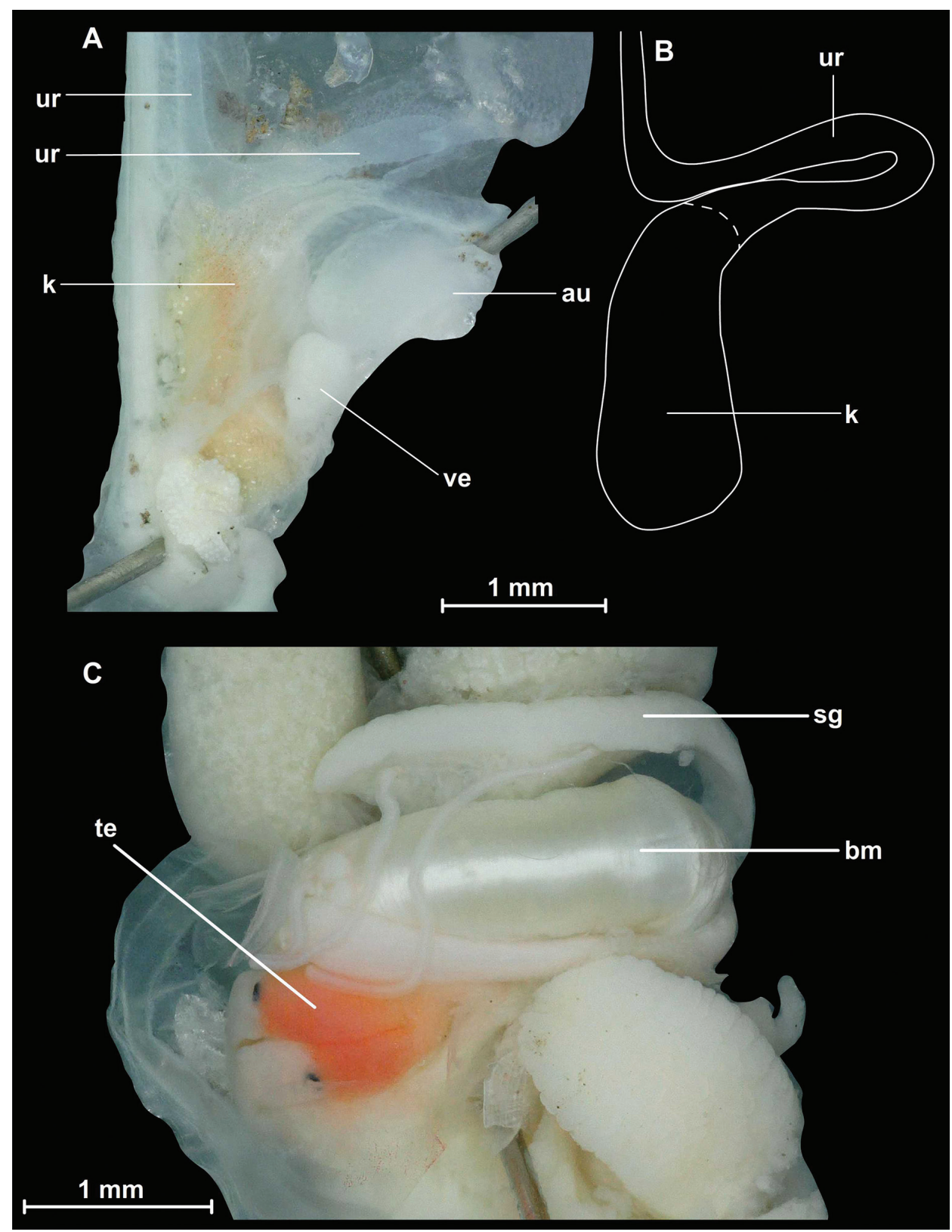

Fig. 2. Excretory system (A-B) and salivary gland and buccal mass (C) of Nagyelma aliena (Bavay and Dautzenberg, 1912). Note that the ureter has been broken during preparation (A). Abbreviations: au: auricle; bm: buccal mass; k: kidney; SG: salivary gland; ve: ventricle; te: tentacles; ur: ureter 


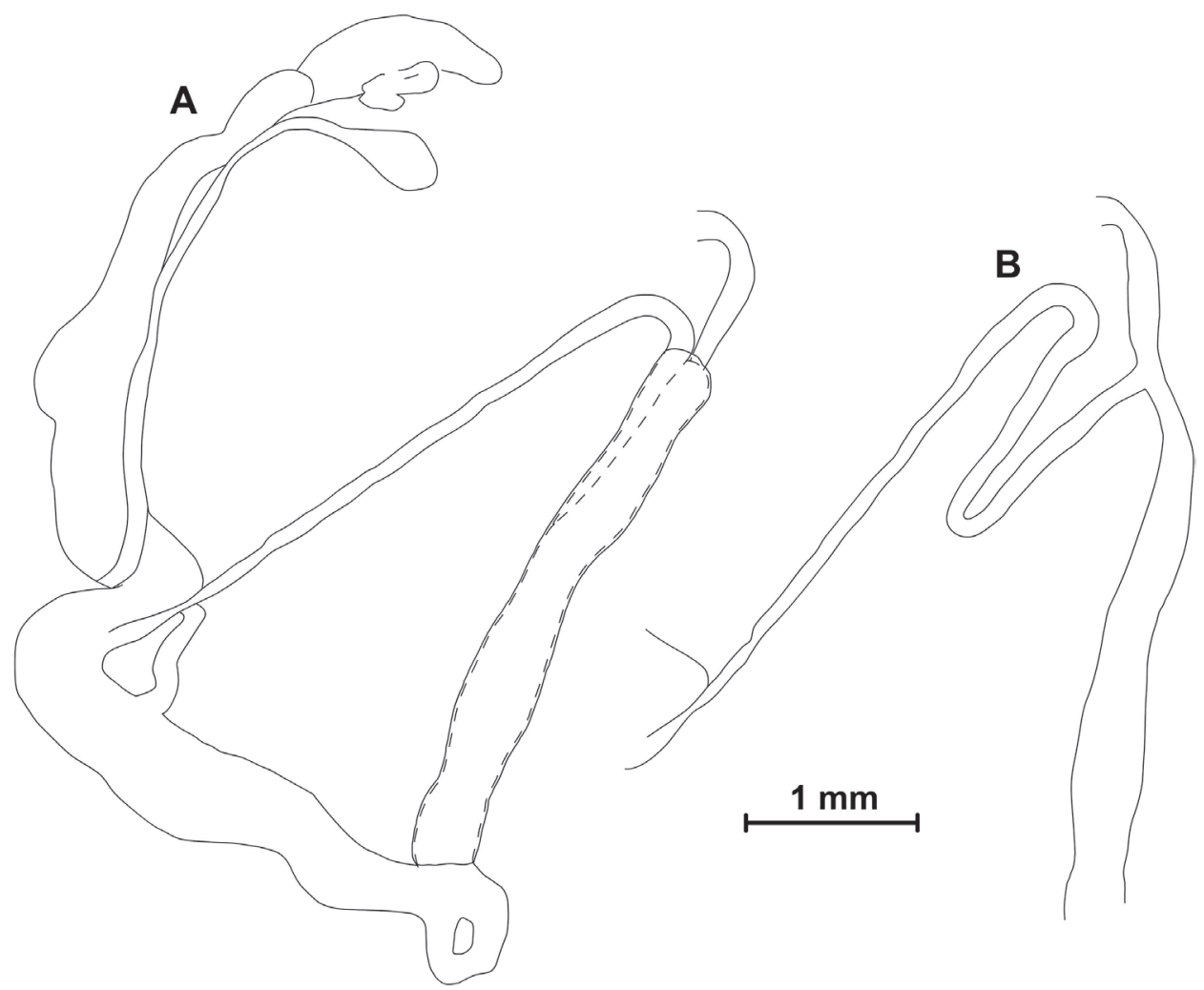

Fig. 3. Reproductive anatomy of Nagyelma aliena (Bavay and Dautzenberg, 1912). A: distal genitalia with intact penial sheath; B: penis and vas deferens after removal of penial sheath

Hemmen, 14.04.2012, HE/1; Vietnam, Thanh Hóa Province, 23.7 km south of Ngọc Lặc, Phúc Thịnh, Làng Miêng, limestone rock above the village, $65 \mathrm{~m}$ a.s.1., $19.93115^{\circ} \mathrm{N}$, $105.36993^{\circ} \mathrm{E}$ (code of coll. site: $2020 / 38$ ), leg. A. Hunyadi, 13.02.2020, HA/1 (photographed), HNHM 104873 (dissected specimen).

Remarks: We were unable to locate Ny-Nham on the map. Schileyko (2011) identifies Nui-Moc (=Thanh Hoa) at the following point within Thank Hoa city: $19^{\circ} 47^{\prime} \mathrm{N}$, $105^{\circ} 49^{\prime} \mathrm{E}$.

We examined newly collected samples from four sites. The samples Vn12-225 and Vn12-269 are situated close to each other in central Thanh Hóa Province, and possess glossy shells, some with a mamillated suture (Fig. 1E). The sample 2020/38 was collected ca. $23 \mathrm{~km}$ southeast from the first two sites, and the shells are somewhat finely ribbed (Fig. 1F). The sample Vn12-268, which was collected ca. $20 \mathrm{~km}$ further southeast (ca. $86 \mathrm{~km}$ from the first two sites) is also ribbed (Fig. 1G). At the moment we consider this to be intraspecific variation.

Pallial complex (Fig. 2A-B): Sigmurethrous, similar to that of Discartemon (see: Siriboon et al., 2014), with kidney sub-rectangular, being ca. twice as long as wide. 


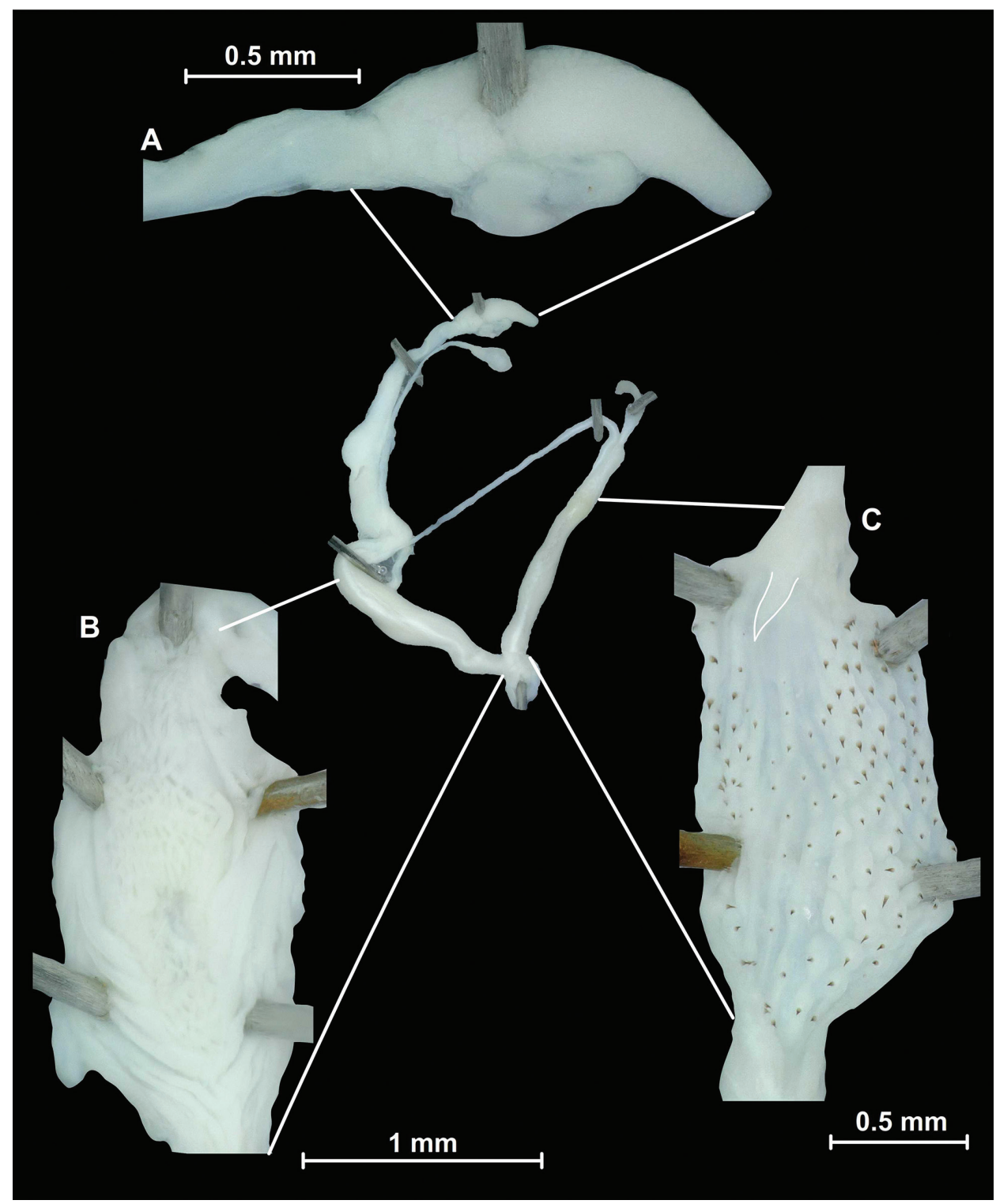

Fig. 4. Reproductive anatomy of Nagyelma aliena (Bavay and Dautzenberg, 1912). A: albumen gland and talon; B: inner wall of the vagina; $\mathrm{C}$ : inner wall of the penis (pointed, fleshy finger-like structure outlined)

Tentacles (Fig. 2C): Bright orange in colour.

Salivary gland (Fig. 2C): Single, soft, elongated, with two ducts leaving separately (rather than together as in Huttonella; Simone, 2013), each duct of even thickness throughout its length (overall similar to that of Elma, see Páll-Gergely et al., 2015). 
Genitalia (Figs. 3, 4): Atrium short; penis long, slender and cylindrical, nearly equally thick throughout; a yellowish knob situated slightly proximal from the centre of penis; between the atrium and the yellowish knob the inner penial wall is covered with scattered papillae, with brown penial hooks in each papilla (Fig. 4C); hooks are largest and more numerous towards the yellowish knob; hooks with sharp tips curved towards the atrium; an elongated, pointed, fleshy finger-like structure is situated on the penis wall at the yellow knob's position, reminiscent of, but not homologous with the penial verge of other stylommatophoran snails (outlined on Fig. 4C); a thin penial sheath present, covering entire penis and the descending and ascending part (loop) of the vas deferens; no epiphallic differentiation observed; vas deferens enters proximal end of penis laterally after forming a loop under the penial sheath; loop ending approximately at the middle of penial sheath, distal from the yellowish knob; diameter of vas deferens somewhat greater where it enters under penial sheath then elsewhere; penial retractor muscle long, thick, inserting at the penis-vas deferens junction and attached to the diaphragm. Vagina relatively long, slightly thicker towards spermoviduct; bursa copulatrix duct long, slender, with ovoid reservoir, reaching the albumen gland; free oviduct short, thicker than penis; inner wall of the vagina and the free oviduct with elevated folds converging towards atrium, and between the folds a longitudinal area with horizontally elongated tiny pockets (Fig. 4B); oviduct enlarged and folded; albumen gland relatively small, pointed; talon small (Fig. 4A), thickened and curved.

\section{Acknowledgements}

We are grateful to Christa Hemmen for providing material for study, and to Ben Rowson to comment on the manuscript. We are indebted to The Biodiversity Heritage Library for the multitude of rare literature made available to us (www.biodiversitylibrary.org). This study was supported by the MTA (Hungarian Academy of Sciences) Premium Post Doctorate Research for B. Páll-Gergely. This study was supported by the Premium Post Doctorate Research Program, the Bolyai Research Scholarship of the Hungarian Academy of Sciences, the Hungarian Research Fund (OTKA FK 135262)

\section{Literature}

Bavay, A. and Dautzenberg, Ph. (1912): Description de coquilles nouvelles de l'Indo-Chine. J. de Conchyliologie $60,1-54$.

Hwang, C.-C. (2014): Annotated type catalogue of land snails collected from Taiwan (Formosa) in the Natural History Museum, London. ZooKeys 428: 1-28.

Gray, J. E. (1860): On the arrangement of the land pulmoniferous Mollusca into families. Annals and Magazine of Natural History, Series 3 6, 267-269.

Páll-Gergely, B. (2017): Should we describe genera without molecular phylogenies? Zootaxa 4232, 593-596.

Páll-Gergely, B., Hunyadi, A., Varga, A. and Rowson, B. (2015): Anatomy and taxonomic position of Elma H. Adams, 1866: A high-spired Southeast-Asian genus of Streptaxidae (Gastropoda: Eupulmonata). Folia Malacologica 23, 155-164. http://dx.doi.org/10.12657/folmal.023.013

Páll-Gergely, B., Hunyadi, A., Grego, J., Sajan, S. K. and Chen, Z.-Y. (2020): A review of the Diapheridae (Gastropoda: Eupulmonata: Streptaxoidea), with special emphasis on India and Myanmar. Raffles Bulletin of Zoology 68, 682-718. DOI: 10.26107/RBZ-2020-0083

Peile, A. J. (1935): Two new species of Sinoennea. Proc. of the Malacological Society of London 21, 382-383.

Rowson, B., Tattersfield, P. and Symondson, W. O. C. (2010): Phylogeny and biogeography of tropical carnivorous land-snails (Pulmonata: Streptaxoidea) with particular reference to East Africa and the Indian Ocean. Zoologica Scripta 40, 85-98. http://dx.doi.org/10.1111/j.1463-6409.2010.00456.x 
Schileyko, A. A. (2000): Treatise on recent terrestrial pulmonate molluscs: Rhytididae, Chlamydephoridae, Systrophiidae, Haplotrematidae, Streptaxidae, Spiraxidae, Oleacinidae, Testacellidae. Ruthenica Suppl. 2, Part 6, 731-880.

Schileyko, A. A. (2011): Check-list of land pulmonate molluscs of Vietnam (Gastropoda: Stylommatophora). Ruthenica 21, 1-68.

Simone, L. R. L. (2013): Anatomy of predator snail Huttonella bicolor, an invasive species in Amazon rainforest, Brazil (Pulmonata, Streptaxidae). Papéis Avul. Zool. Mus. Zool. Univ. São Paulo 53, 47-58.

Siriboon, T., Sutcharit, C., Naggs, F., Rowson, B. and Panha, S. (2014): Revision of the carnivorous snail genus Discartemon Pfeiffer, 1856, with description of twelve new species (Pulmonata, Streptaxidae). ZooKeys 401, 45-107. doi: 10.3897/zookeys.401.7075

Siriboon, T., Naggs, F., Wade, C. W., Jeratthitikul, E., Tongkerd, P., Jirapatrasilp, P., Panha, S. and Sutcharit, C. (in press): Phylogenetic relationships of the carnivorous terrestrial snail family Streptaxidae (Stylommatophora: Achatinina) in Thailand and surrounding areas of Southeast Asia. Systematics and Biodiversity

Sutcharit, C., Naggs, F., Wade, C. M., Fontanilla, I. and Panha, S. (2010): The new family Diapheridae, a new species of Diaphera Albers from Thailand, and the position of the Diapheridae within a molecular phylogeny of the Streptaxoidea (Pulmonata: Stylommatophora). Zoological J. Linnean Society 160, 1-16. https://doi.org/10.1111/j.1096-3642.2009.00598.x

Varga, A. (2012): On the genus Elma H. Adams, 1866 (Mollusca, Streptaxidae). Folia Historico Naturalis Musei Matraensis 36, 5-13.

Open Access statement. This is an open-access article distributed under the terms of the Creative Commons Attribution 4.0 International License (https://creativecommons.org/licenses/by/4.0/), which permits unrestricted use, distribution, and reproduction in any medium, provided the original author and source are credited, a link to the CC License is provided, and changes - if any - are indicated. (SID_1) 
